https://dx.doi.org/10.4314/iijikm.v10i1.1

Information Impact:

Journal of Information and Knowledge Management

Vol. 10 (1), June, 2019

ISSN: 2141-4297 (Print) ISSN: 2360-994X (Online)

\title{
Determinants of the Quality of Research Outputs by Librarians in Selected University Libraries in South East Nigeria
}

\author{
${ }^{1}$ Josephine C. Igbokwe, ${ }^{2 *}$ Oyemike Victor Benson, ${ }^{3}$ Fidelia Ngozi Enem \\ ${ }^{1}$ Cataloguing Section, University Library, University of Nigeria Nsukka \\ ${ }^{2}$ Department of Library and Information Science, Federal Polytechnic, Nekede, Owerri ,Imo State \\ ${ }^{3}$ Senior Librarian, University Library, University of Nigeria, Enugu Campus \\ *Corresponding author greatoyemike@yahoo.com, bensonoyemike@gmail.com
}

\begin{abstract}
The purpose of the study is to examine the determinants of the quality of research outputs by librarians in university libraries from the south east of Nigeria. The survey design was adopted for the study. The population comprises librarians from 6 universities in south east. Total enumeration technique was used to cover all librarians for the study. The questionnaire was used for data collection. A total of one hundred and nine (109) copies of questionnaires were distributed to librarians in the selected library with a return rate of $69.7 \%$. The study used descriptive statistics in analyzing data generated for the study. The result revealed that the librarians' research skills, editors' level of editorial competency and mentor mentee relationships of librarians are all determining factor in relation to the quality of research outputs by librarians. There is a dire need for library associations and heads of university libraries to organize seminars / workshops on research methods, this would help librarians to acquire the necessary skills required for quality research output. Also, editors in library and information science journals should come under one umbrella to enable them share their editorial experiences with other editors. The study has provided empirical evidence in research skills, editors' competency / areas of specialization and mentor-mentee relationship as determining factor for quality of research outputs by librarians.
\end{abstract}

\section{Keywords: Research Quality, Librarians', University Libraries, South-East, Editors' Competency, Mentor-Mentee Relationship}

\section{Introduction}

Librarians are accorded the status of academic staff in academic community. This also confers on them the responsibility of carrying out research and publishing same in reputable and peer reviewed journals. The progression of librarians in university libraries from one cadre level to another places a demand on them to have number of papers published in both local and international journals, combine with papers presented at both local and international conferences. The importance of research to a 
university cannot be over emphasized, it leads to generation of new knowledge, engenders innovations, enhances the quality of teaching staff, increases an institutions reputation and its economic status (Sulo et $a l, 2012)$. However, it is worthy to point out that it is not just the number of papers published or presented that guarantees promotion but the quality. These papers are usually subjected to appraisal to ascertain the quality of such paper.

The scholarly community is in general agreement that scholarly research output should be of high quality, published through a solid peer-review process in an acceptable format, and accessible in the form of recorded sources in print and electronic format such as books (monograph, chapters in books, conference papers and proceedings, articles in scholarly journal, theses and dissertations, patents and trademarks, and creative works, such as performance and exhibitions of the arts, among others (Ocholla, Ocholla \& Onyancha, 2013).

The quality of research as noted by Mahmood (2011) is a question mark for many developing as well as developed countries. Research quality is the cornerstone of modern science, it aids in the understanding of reputational differences among scientific and academic institutions (Garcia \& Menedez, 2004). Quality includes elements such as clarity, technical corrections, importance and relevance, interest to readers (D'Andrea \& O'Dwyer 2017). Quality refers to the conformance to requirement. This implies that quality research is that research which bears all the peculiarities required by its user (Mahmood, 2011). This to him may have internally and externally valid research design, reliable data sources, free from plagiarism practice, application of appropriate tools, and meaningful interpretation of results in practical and statistical terms (Fink, 1998 as cited in Mahmood, 2011).

Research revolves around the need for scientific evidence on which professional practices can be based upon. Research plays a key role in development and dissemination of knowledge; it leads to development of new knowledge as well as contributing to existing knowledge (Sulo et al, 2012). Academic research represents the backbone of human activity in the way that it improves our quality of life through expanding frontiers of academic knowledge and making further research possible throughout the world (Alzahrani, 2011). Nevertheless, quality of research is influenced by many factors (variables) such as librarians' research skills, editors' competency/areas of specialization and mentor-mentee relationship.

Editors and reviewers play a critical role as gatekeepers for contributions to scientific literature (Fox, Burns \& Meyer, 2015). Editorial peer review is therefore an extension of the basic principles of science and scholarship (Jefferson, Wager \& Dandoff, 2002). Lukic and Marusic (2001) posit that the appointment of statistical editor in small journal is not a guarantee for the improvement of statistics in manuscripts. It seems that most problems arise from the inadequate editorial practice. Editors are responsible not only for technical perfection but also for the following of ethical standards in all phases of publication process (Bogdanovic, 2003). Journal editors serve a vital role in the academic world because they are seen as the gatekeepers of 
new scientific knowledge (Aguinis \& Vaschetto, 2011).

Mentoring is a process for the informal transmission of knowledge, social capital, and the psychosocial support perceived by the recipient as relevant to work, career, or professional development. Mentoring entails informal communication usually face-to-face and during a sustained period of time between a person who is perceived to have greater relevant knowledge, wisdom, or experience (the mentor) and person who is perceived to have less (the mentee) (Ekechukwu \& Horsfall, 2015). Relationship between mentor-mentee therefore influences the quality of research. Mentors support the individual academics to develop and maintain their research profile and activities. The primary role for research mentors is to

\section{Literature Review}

According to Pfund et al (2016:3), despite evidence of mentoring's importance, little is known about the complexities of research relationships both in terms of how individual cultural difference factors like race ethnicity, and gender influence these relationships as well as the effectiveness or different forms of mentoring. They affirmed that successful mentoring relationship can be measured by a mentee's success in reaching individual milestones that allow her or him to progress to the next stage along the trajectory for a sustainable career. Mahmood (2011) revealed the perceptions of the students about the supervisors, about time, experience, training and modern techniques and it was not in the favour of the supervisors. The finding showed that supervisors are a factor affecting the quality provide encouragement for, and show an interest in, their mentee's research plans and activities (Wadesango, 2014). From the fore going, librarians research skills, editors competency/areas of specialization and mentor-mentee relationship are determinants of quality research outputs by librarians in university libraries. It is against this backdrop that this study seeks answers to the following questions:

1. How do librarians research skills influence quality of research outputs by librarians?

2. How does editors' competency/areas of specialization impacts on quality of research output among librarians?

3. How does mentor-mentee relationship affects the quality of research outputs by librarians?

of research. Supervisors are mentors, however, it was noted that supervisors and being a teacher, being not well trained will affect the quality of research. In which case, the teacher who is like a mentor affects the quality of research outcome especially when they are incompetent.

Wadesango (2014) contend that research mentors help new staff members with appropriate time planning and management, suggesting time deadlines for achieving agreed targets and checking that these are met. Okoduwa et al (2018) identified barriers to research activities, these include lack of suitably qualified mentoring with appropriate expertise and sufficient time for mentoring, limited resources such as funds and facilities and logical difficulties. 
D'Andrea and D'Dwyer (2017) found out that editors can mitigate, but not neutralize, the impact of indifference to quality by forwarding disputed manuscripts to tiebreaking references, or alternatively by working with three references rather than two. This implies that editor to some extent exert influence on the quality of research. Aguinis and Vaschetto (2011) citing Wright (2011) much like an organization's actions and policies, the actions and policies of a journal editor also have the ability to affect several primary and secondary stakeholders at different levels of analysis. As noted by Neds-Fox and Archuleta (2014), editor experience is a strong driver of expectations (in addition to impacting the developmental stage of the journal). Editors will have widely varying expectations depending on prior experience (or lack thereof) with library and/ or commercial publisher.

Herteliu et al (2017) observed that editors have the ability to influence the hindex of authors. According to Bogdanovic (2003), the quality of journals rests, to a large degree, on the quality of peer review process. Kleinert and Wager (2011) posit that editors should regard themselves as part of the wider professional editorial

\section{Methodology}

The study adopted a descriptive survey research design. The study population was librarians of four state-owned and 4 federalowned university libraries out of the five states in south east Nigeria. The states from which the institutions were selected include Abia, Anambra, Enugu and Imo States. The study sample consists of all the librarians because the enumeration sample was used. Data were collected through questionnaire community, keep themselves abreast of relevant policies and developments, and ensure their editorial staff is trained and kept informed of relevant issues.

Wadesango (2014) in his study established that there are measures that can be put in place in an endeavour to promote research output and publication such as: mentoring by established researchers, training workshops, established collaboration research areas, providing funding, allowing research time out for research and recognizing excellence in teaching through research led initiatives. Brown, Wolski and Richardson (2015) affirmed that while formal skills training is important as librarians move into new research support roles, there is also a critical need for informal training, mentoring and support networks. Also, library roles which support research need to be scoped to determined the skills and expertise required within a team, faculty and the institution. They further state the need to have an indepth knowledge of the research process in specific discipline areas to be able to contribute as full partners in the research activity.

administered with the help of research assistants. The instrument consists of 33 items statements divided into three sections based on the research questions. Section 1 focused on librarians research skills influences on the quality of research outputs with 11 items statements; section 2 focused how editors' competency / areas of specialization influences quality of research output with 10 items statement, while the last section dwelt on the influence of mentor - mentee relationship and its impact on the 
quality of research outputs by librarians with a total of 12 item statements. The responses to the questionnaire items were chosen from a 4 - point Likert-like scale where $4=$ strongly agree, $3=$ agree, $2=$ disagree and 1 $=$ strongly disagree. The analysis of the data was intended to answer 3 basic research questions about the determinants of the quality of research outputs by librarians in university libraries in south east Nigeria. Out of the one hundred and nine (109) questionnaires distributed, seventy six (76) were returned fully answered indicating response rate of $69.7 \%$. The data generated were analyzed using descriptive statistics.

\section{Population of study}

\begin{tabular}{|l|l|c|c|}
\hline S/NO. & Name of Institution/Library & $\begin{array}{l}\text { Copies of } \\
\text { Instrument } \\
\text { Administered } \\
\text { to Librarians }\end{array}$ & $\begin{array}{c}\text { Copies of } \\
\text { Instrument } \\
\text { Received from } \\
\text { Librarians }\end{array}$ \\
\hline 1. & Abia State University Library & 3 & 3 \\
\hline 2. & Imo State University Library, Owerri & 20 & 8 \\
\hline 3. & $\begin{array}{l}\text { Chukwuemeka Odimegwu Ojukwu } \\
\text { Library }\end{array}$ & 12 & 6 \\
\hline 4. & Enugu State University Library & 11 & 11 \\
\hline 5. & $\begin{array}{l}\text { Michael Okpara University of Agriculture, } \\
\text { Umudike }\end{array}$ & 13 & 12 \\
\hline 6. & University of Nigeria Nsukka Library & 32 & 21 \\
\hline 7. & Nnamdi Azikwe, Awka & 15 & 4 \\
\hline 8. & $\begin{array}{l}\text { Federal University of Technology Library, } \\
\text { Owerri }\end{array}$ & 33 & 13 \\
\hline & Total & $\mathbf{1 0 9}$ & $\mathbf{7 6}$ (69.7\%) \\
\hline
\end{tabular}




\section{Presentation of Result}

Table 1: Mean $(\bar{x})$ scores of the responses of librarian on influence of librarians' research skills on quality of research outputs

\begin{tabular}{|c|c|c|c|c|c|c|c|c|}
\hline & $\begin{array}{l}\text { How librarians research skills influences the } \\
\text { quality of their research outputs includes }\end{array}$ & $\mathbf{S A}$ & $\mathbf{A}$ & D & SD & Total & Mean & $\begin{array}{c}\text { Standard } \\
\text { Dev. }\end{array}$ \\
\hline a. & $\begin{array}{l}\text { inability to adopt appropriate research methods } \\
\text { leads to poor quality of research; }\end{array}$ & 47 & 25 & 2 & 2 & 76 & 3.54 & 0.682 \\
\hline b. & $\begin{array}{l}\text { possessing of the right research skills will lead to } \\
\text { producing quality research by librarians; }\end{array}$ & 48 & 24 & 0 & 4 & 76 & 3.53 & 0.757 \\
\hline c. & $\begin{array}{l}\text { knowing the right sources to consult and cite is } \\
\text { based on right research skills; }\end{array}$ & 36 & 36 & 0 & 4 & 76 & 3.37 & 0.746 \\
\hline d. & $\begin{array}{l}\text { application of appropriate research methods is } \\
\text { possible without research skills among librarians; }\end{array}$ & 8 & 21 & 26 & 21 & 76 & 2.21 & 0.97 \\
\hline e. & $\begin{array}{l}\text { deficiency in research skills affects the quality of } \\
\text { research outputs by librarians; }\end{array}$ & 35 & 24 & 1 & 16 & 76 & 3.03 & 1.154 \\
\hline f. & $\begin{array}{l}\text { inappropriate statement of the problem affect the } \\
\text { framing of research questions among librarians; }\end{array}$ & 28 & 39 & 2 & 7 & 76 & 3.16 & 0.865 \\
\hline g. & $\begin{array}{l}\text { accurate stating of the research questions depends } \\
\text { on the librarians research skills; }\end{array}$ & 24 & 41 & 6 & 5 & 76 & 3.11 & 0.81 \\
\hline h. & $\begin{array}{l}\text { poor research skills does not affect the framing of } \\
\text { research questions among librarians; }\end{array}$ & 11 & 17 & 25 & 23 & 76 & 2.21 & 1.037 \\
\hline i. & $\begin{array}{l}\text { possessing of research skills affects librarians } \\
\text { citation pattern; }\end{array}$ & 19 & 35 & 14 & 8 & 76 & 2.86 & 0.919 \\
\hline $\mathrm{j}$. & $\begin{array}{l}\text { possessing of research skills is crucial in } \\
\text { information retrieval for quality research by } \\
\text { librarians; and }\end{array}$ & 31 & 38 & 2 & 5 & 76 & 3.25 & 0.802 \\
\hline \multirow[t]{2}{*}{ h. } & $\begin{array}{l}\text { possessing the right research skills affect } \\
\text { librarians' use of electronic resources in research } \\
\text { and the quality of research output }\end{array}$ & 28 & 34 & 4 & 10 & 76 & 3.05 & 0.978 \\
\hline & & & & & & Grand & 3.03 & 0.806 \\
\hline
\end{tabular}

The mean responses on how librarians' research skills influence the quality of their research outputs as shown in table 1, indicates that majority of the respondents agree to almost all the item statements. This include inability to adopt appropriate research methods leads to poor quality research $(\bar{x}=3.54 ; \mathrm{SD}=0.682)$; possessing of the right research skills will lead to producing quality research by librarians $(\bar{x}=3.54$; $\mathrm{SD}=0.757)$; knowing the right sources to consult and cite is based on right research skills $(\bar{X}=3.37 ; \mathrm{SD}=$ 0.757); deficiency in research skills affects the quality of research outputs by librarians $(\bar{x}=3.03 ; \quad \mathrm{SD}=1.54) ;$ inappropriate statement of the problem affect the framing of research questions among librarians $(\bar{X}=$ 
3.16; $\mathrm{SD}=0.865)$; accurate stating of the research questions depends on the librarian research skills $(\bar{x}=3.11 ; \mathrm{SD}=0.81)$; possessing of research skills affects librarians citation pattern $(\bar{x}=2.86, \mathrm{SD}=$ 0.919); possessing of research skills is crucial in information retrieval for quality research by librarians $(\bar{x}=3.25, \mathrm{SD}=$ 0.802); and possessing the right research skills affect librarians use of electronic resources in research and the quality of research $(\bar{x}=3.05$; SD $=0.978)$. However, some of the respondents disagree with the fact that application of appropriate research methods is possible without research skills among librarians $(\overline{\mathcal{X}}=2.21 ; \mathrm{SD}=0.97)$ and poor research skills does not affect the framing of research questions among librarians $(\bar{x}=2.21$; SD 1.037).

Table 2: Mean $(\bar{x})$ scores of the responses of librarian on how editors, competency / areas of specialization influence on quality of research output among librarians.

\begin{tabular}{|c|c|c|c|c|c|c|c|c|}
\hline $\mathbf{S} / \mathbf{N}$ & $\begin{array}{l}\text { editors' competency/areas of specialization } \\
\text { influence on quality of research output among } \\
\text { librarians }\end{array}$ & $\mathbf{S A}$ & $\mathbf{A}$ & D & SD & Total & Mean & $\begin{array}{l}\text { Standard } \\
\text { Dev. }\end{array}$ \\
\hline a. & $\begin{array}{l}\text { editors' liberality affects quality of research by } \\
\text { librarians; }\end{array}$ & 17 & 41 & 7 & 11 & 76 & 2.84 & 0.939 \\
\hline b. & $\begin{array}{l}\text { editors' inadequate knowledge of research } \\
\text { methods affects quality of research by librarians; }\end{array}$ & 32 & 36 & 4 & 4 & 76 & 3.26 & 0.789 \\
\hline c. & $\begin{array}{l}\text { editors research capacity helps to improve the } \\
\text { quality of research output among librarians; }\end{array}$ & 32 & 37 & 2 & 5 & 76 & 3.26 & 0.806 \\
\hline d. & $\begin{array}{l}\text { poor editorial input affects the quality of research } \\
\text { output by librarians; }\end{array}$ & 32 & 26 & 11 & 7 & 76 & 3.09 & 0.969 \\
\hline e. & $\begin{array}{l}\text { editors overzealousness affects the quality of } \\
\text { research outputs by librarians; }\end{array}$ & 18 & 33 & 18 & 7 & 76 & 2.82 & 0.905 \\
\hline f. & $\begin{array}{l}\text { editors level of editorial competency affects the } \\
\text { quality of research outputs among librarians; }\end{array}$ & 31 & 37 & 7 & 1 & 76 & 3.29 & 0.689 \\
\hline g. & $\begin{array}{l}\text { editors area of specialization influences the } \\
\text { quality of research outputs by librarians; } \\
\text { editors research capacity can have a positive }\end{array}$ & 22 & 41 & 8 & 5 & 76 & 3.05 & 0.815 \\
\hline h. & $\begin{array}{l}\text { effect on the quality of research outputs by } \\
\text { librarians; }\end{array}$ & 23 & 37 & 5 & 11 & 76 & 2.95 & 0.978 \\
\hline I & $\begin{array}{l}\text { the prejudice of an editor affects the quality of } \\
\text { research outputs by librarians; }\end{array}$ & 21 & 29 & 9 & 17 & 76 & 2.71 & 1.105 \\
\hline \multirow[t]{2}{*}{ J } & $\begin{array}{l}\text { editors lack of expertise in the use of technology } \\
\text { for editorial work affect the quality of research } \\
\text { outputs by librarians; }\end{array}$ & 25 & 36 & 10 & 5 & 76 & 3.07 & 0.854 \\
\hline & & & & & & Grand & 3.03 & 0.832 \\
\hline
\end{tabular}


As shown in table 2, at a grand mean of 3.03 and standard deviation of 0.832 , the respondents agreed that editor's competency / areas of specialization influence the quality of research output among librarians. The respondents agreed to all the 10 item statements on editors' competency / areas of specialization influence on quality of research output among librarians. However, the notable ones include editors' inadequate knowledge of research methods affect quality of research by librarians $(\bar{x}=3.26$,
$\mathrm{SD}=0.789$ ); editors research capacity helps to improve the quality of research output among librarians $(\bar{x}=3.26 ; \mathrm{SD}=0.806)$; editors' level of editorial competency affects the quality of research outputs among librarians $(\bar{x}=3.26$; SD $=0.806)$; editors area of specialization influences the quality of research outputs by librarians $(\bar{x}=3.05$; $\mathrm{SD}=0.815)$ and editorial work affect the quality of research outputs by librarians $(\bar{X}=$ 3.07; SD = 0.854).

Table 3: Mean $(\bar{X})$ scores of the responses of librarian on how mentor-mentee relationship influences the quality of research outputs by librarians

\begin{tabular}{|c|c|c|c|c|c|c|c|c|}
\hline $\mathbf{S} / \mathbf{N}$ & $\begin{array}{l}\text { Influence of mentor-mentee relationship on the } \\
\text { quality of research outputs by librarians includes }\end{array}$ & $\mathbf{S A}$ & $\mathbf{A}$ & D & SD & Total & Mean & $\begin{array}{c}\text { Standard } \\
\text { Dev. }\end{array}$ \\
\hline a. & $\begin{array}{l}\text { effective mentor-mentee relationship does not affect } \\
\text { the quality of research outputs of librarians; }\end{array}$ & 7 & 20 & 31 & 18 & 76 & 2.21 & 0.914 \\
\hline b. & $\begin{array}{l}\text { joint-research with mentors help to improve the } \\
\text { quality of research outputs of librarians; }\end{array}$ & 38 & 34 & 0 & 4 & 76 & 3.39 & 0.75 \\
\hline c. & $\begin{array}{l}\text { the weakness of mentors influences the quality of } \\
\text { research by their mentees; }\end{array}$ & 22 & 30 & 5 & 19 & 76 & 2.72 & 1.138 \\
\hline d. & $\begin{array}{l}\text { mentors research capacity affects the quality of } \\
\text { research output by librarians; }\end{array}$ & 31 & 33 & 7 & 5 & 76 & 3.18 & 0.86 \\
\hline e. & $\begin{array}{l}\text { most librarians are not receiving adequate research } \\
\text { mentoring from their mentors and it affects the } \\
\text { quality of their research outputs; } \\
\text { most mentors are not willing to effectively mentor }\end{array}$ & 23 & 41 & 8 & 4 & 76 & 3.09 & 0.786 \\
\hline f. & their mentee and this reflects on the research & 21 & 39 & 11 & 5 & 76 & 3 & 0.833 \\
\hline $\mathrm{g}$ & $\begin{array}{l}\text { differences in areas of interest between mentors and } \\
\text { mentee affects the quality of research outputs } \\
\text { among librarians; }\end{array}$ & 15 & 18 & 7 & 36 & 76 & 2.16 & 1.223 \\
\hline h. & $\begin{array}{l}\text { gender of research mentors do not provide room for } \\
\text { effective research mentoring and it affects quality of } \\
\text { librarians research outputs;; }\end{array}$ & 18 & 21 & 33 & 4 & 76 & 2.7 & 0.895 \\
\hline i. & $\begin{array}{l}\text { the quality of librarians' research has fallen due to } \\
\text { disregard for mentoring among librarians; }\end{array}$ & 16 & 28 & 18 & 14 & 76 & 2.61 & 1.021 \\
\hline $\mathrm{j}$. & $\begin{array}{l}\text { the quality of research outputs by librarians is } \\
\text { dropping because of poor mentoring; }\end{array}$ & 20 & 30 & 17 & 9 & 76 & 2.8 & 0.966 \\
\hline
\end{tabular}


Igbokwe,J.C, Benson, O.V, Enem, F.N: Determinanats of the Quality of Research Outputs by Librarians in Selected University Libraries in South East Nigeria
k. encouragement from mentors affects the good quality of research output of librarians; and
$27 \quad 40 \quad 5 \quad 4 \quad 76$
3.18
0.778
discouragement from mentors affect the quality of research outputs of librarians.
$\begin{array}{llllll}13 & 41 & 17 & 5 & 76 & 2.82\end{array}$
0.795

At the grand mean of 2.82 and standard deviation of 0.844 , majority of the respondents reported that mentor-mentee relationship influences the quality of research outputs by librarians. As shown in the responses in Table 3, the respondents agreed to 10 out of the 12 item statements. The five areas mostly agreed by the librarians on the influence of mentor-mentee relationship on the quality of research outputs of librarians include: joint-research with mentors help to improve the quality of research outputs of librarians $(\bar{x}=3.39$; SD $=0.75)$; mentors research capacity affects the quality of research output by librarians $(\bar{X}=3.18 ; \mathrm{SD}=0.86)$; encouragement from mentors affects the good quality of research

\section{Discussion of Results}

The result of this study is discussed under the following sub-heading: influence of librarians' research skills on the quality of their research output; editors' competency / areas of specialization influence on quality of research output among librarians; and mentor-mentee relationship influence on quality of research output among librarians.

\section{Influence of librarians' research skills on the quality of their research output}

The results in table 1 reveals that librarians research skills greatly influence the quality of research outputs among librarians. The finding indicates that output of librarians $(\bar{x}=3.18$; SD $=0.778)$. Most librarians are not receiving adequate research mentoring from their mentors and it affects the quality of their research outputs $(\bar{x}=3.09 ; \mathrm{SD}=0.786)$; and most mentors are not willing to effectively mentor their mentee and this reflects on the research outputs of librarians ( $\bar{X}=3.0 ; \mathrm{SD}=0.833)$. The 2 items they disagreed are that: effective mentor-mentee relationship does not affect the quality of research outputs of librarians $(\bar{X}=2.21 ; \quad \mathrm{SD}=0.914)$ and differences in areas of interest between mentors and mentee affects the quality of research outputs among librarians $(\bar{X}=2.16$; $\mathrm{SD}=1.223$ ).

inability to adopt appropriate research methods leads to poor quality of research while possessing the right research skills leads to producing quality research. This aligned with the submissions of Masango (n.d.) that the lack of appropriate research knowledge may inhibit the production of quality research outputs. It further corroborates the view of Brown, Wolski and Richardson (2015), when they stated the need to have in-depth knowledge of the research process in specific discipline areas to be able to contribute as a full partner in the research activity. 


\section{Editors' competency / areas of specialization influence on quality of research output among librarians}

The result of this study reveals that editors' level of competency and area of specialization has great influence on quality of research output among librarians. This is in line with the submissions of D'Andrea and D'Dwyer (2017) that editors can initiate but not neutralized the impact of indifference to quality. This further validates the assertion of Fox, Burns and Meyer (2015) that editors and reviewers play a critical role as gatekeepers for contributions to scientific literature. The summary of the findings here is that editors' inadequate knowledge of research methods affects the quality of research by librarians and poor editorial inputs. Also, the editors' research capacity can have a positive effect on the quality of research outputs just the same way editors liberality affects the quality of research by librarians. This is also in line with the submission of Neds-Fox and Archuleta (2014), that editor experience is a

\section{Conclusion}

Based on the analysis and discussions of results of this study, the conclusions below are drawn with reference to the research questions. The findings proved that librarians research skills influences the quality of their research outputs because the inability to adopt appropriate research methods by librarians may lead to poor quality of research where as the possession of the right research skills will lead to producing quality research. It is also established that the application of appropriate research methods is not possible strong driver of expectations (in addition to impacting the developmental stage of the journal).

\section{Mentor-mentee relationship influence on quality of research output among librarians}

The result of this study indicates that relationship between mentor and mentee influences the quality of librarians' research output. It shows that joint research with mentors, mentors research capacity and encouragement from mentors affects the quality of research outputs by librarians. Likewise the weakness of mentors and unwillingness of most mentors to effectively mentor their mentee reflects on the research outputs of librarians. This finding is in agreement with Okoduwa et al (2018), that barrier to research activities include lack of suitably qualified mentors with appropriate expertise and sufficient time for mentoring. It also aligns with Pitout (2014), that in the research process, availability of mentorship is important. without research skills among librarians in university libraries. Also, the editors' competency and areas of specialization significantly influence the quality of research outputs among librarians. The influence may be positive or negative depending on the editor's level of editorial competency, research capacity, area of specialization and the prejudice of the editor. Furthermore, the mentor-mentee relationship of librarians influenced the quality of research outputs. This influence may be positive or negative; this however, depends on mentors' research capacity, 
willingness of librarians to be mentored, encouragement from mentors as well as Implications of the Study

The educational and professional implication derived from the results of this study is that: there is a dire need for library associations and heads of university libraries to organize conference and workshops that are research focused. This will help in equipping libraries with the requisite research skills considering the relevance of research skills on the quality of their research outputs. Furthermore, the results has prove that editors competency/ areas of specialization influence the quality of research output among librarians, this implies that measures should be put in place to check the competency of editors' in library and information science journals. In other words, only editors with proven research skills and high level of editorial competency should be engaged in editorial processes.

\section{Recommendations}

The following recommendations were made in line with the findings of the study: They are:

i. Librarians should explore every opportunity available to them to improve on their research skills. Conferences should be organized for librarians; these conferences should be research-based conferences, whereby seasoned researchers should be used as resource persons. Efforts should be made to ensure that these conferences are practical oriented. discouragement from mentors.

More so, editors should not be given works outside their areas of specialization or interests. Professionally, there is need for editors in library and information science journals to come under a professional body or association, where they can be meeting to brainstorm and share ideas on best practices in editorial work. The findings of the study indicate that mentor-mentee relationship influences the quality of research outputs among librarians. This implies that librarians should braze up and harness the relationship with their mentors to improve the quality of their research output; this however, is subject to the research capacity of these mentors as well as their willingness to mentor their mentee and the readiness of librarians to be mentored in research process.

ii. There is need for editors in librarianship to come under one forum, whereby they could share their experiences. It would also be used as platform for retraining the editors on editorial techniques and the application of ICT tools in editorial process.

iii. Librarians should submit themselves for mentorship. This would afford them the opportunity of understanding the rudiment of research. Research is dynamic and a continuous process, having a cordial relationship with mentors with adequate knowledge of research methods will enable them to acquire research skills. 


\section{References}

Aguinis, H. \& Vaschetto, S. J. (2011). Editorial responsibility: managing the publishing process to do good and do well. Management and Organization Review, 7 (3), 407 - 422. Doi: 10.111/j.1740-8784.2011.00223.x

Alzahrani, J. A. (2011). Overcoming barriers to improve research productivity in Saudi Arabia. International Journal of Business and Social Science, 2 (19) 5057

Bogdanovic, G. (2003). Publication ethics: the editor-author relationship. Archive of Oncology, 11 (3), 213 - 215

Brown, R. A., Wolskin, M. \& Richardson, J. (2015). Developing new skills for research support librarians, The Australian Library Journal, 64 (3), 224234

D’Andrea, R. \& O’Dwyer, J. P. (2017). Can editors save peer review from peer reviewers? Plos ONE, 12 (10):e0186111

Ekechukwu, R. O. \& Horsfall, M. N. (2015). Academic mentoring in higher education: a strategy to quality assurance. Journal of Research and Reflection in Education Science, 3 (2), 37-45

Fox, C. W., Burns, C. C. \& Meyer, J. A. (2015). Editor and reviewer gender influence the peer reviewer process but not peer review outcomes at an ecology journal. Functional Ecology, doi: 10.1111/1365-2435.12529.

Garcia, C. E. \& Menendez, L. S. (2004). Competition for funding as an indicator of research competitiveness: the Spanish R\& D government funding. Available online at: ftp://ftp.repec.org/opt/ReDIF/RePEc/ipp/ wpaper/dt-0415.pdf

Hadjinicola, G. C. \& Soteriou, A. C. (2006). Factors affecting research productivity of production and operations management groups: an empirical study. Journal of Applied Mathematics and Decision Sciences, 2006 (96542), 1-16. Doi: 10.1155/JAMDS/2006/96542.

Herteliu, C., Ausloos, M., Ileanu, B. V., Rotundo, G. \& Andrei, T. (2017). Quantitative and qualitative analysis of editors' behavior through potential coercive citations. Available online at:

Jefferson, T., Wager, E. \& Davidoff, F. (2002). Measuring the quality of editorial peer. JAMA, 287 (21), 27862790 .

Jubb, M. (2006). The Uk's research information infrastructure: key issues and challenges. LBER QUARTERLY, $16(3 / 4)$, available online at http://liber.library.uu.nl/volume16issue ${ }^{3}$ / $4 \underline{2006 .}$.

Kleinert, S. \& Wager, E. (2011). Responsible research publication: international standards for editors. A position statement developed at the $2^{\text {nd }}$ World Conference on Research Integrity Singapore, July 22-24, 2010. Chapter 51 in: Mayer, T. and Steneck, N (eds.) Promoting Research integrity in a Global Environment Imperial College Press/World Scientific Publishing, Singapore (pp.317.-.328) 
Lukic, I. K. \& Marusic, M. (2001). Appointment of statistical editor and quality of statistics in a small medical journal. Croatian Medical Journal, 42 (5), 500-503

Mahmood, S. T. (2011). Factors affecting the quality of research in education: students' perceptions. Journal of Education and Practice, 1(11\& 2), 3439

Masango, C. A. (n.d.). Combating inhibitors of quality research outputs at the University of Cape Town. The Journal of Research Administration, 46 (1), 1123. Available online at: https://files.eric.ed.gov/fulltext/EJ11560 82.pdf

Neds-Fox, J. \& Archuleta, K. L. (2014). Alignment with editors' expectations. Journal of Librarianship and Scholarly Communication, 2 (4): eP11 78. http://dx/doi. org/10.7710/2162$\underline{3309.1178}$

Ocholla, D. \& Ocholla, L, (2013). Insight into research publication output of academic librarians in southern African public universities from 2002 to 2011. African Journal of Library, Archival \& Information Science, 23 (1), 5 -22

Okoduwa, S. I. R., Abe, J. O., Samuel, B. I., Chris, A. O., Oladimeji, R. O., Idowu, O. O. \& Okoduwa, U. J. (2018). Attitudes, perception and barriers to research and publishing among research and teaching staff: a case study. doi: http://dx.doi.org/10.1101/347112
Pfund, C., Byars- Winston, A., Branchaw, J., Hurtado, S. \& Egan, K. (2016). Defining attritutes and metrics of effective research mentoring relationships. AIDS Beharm 20 (suppl 2), 238-248. Doi: 10.1007/SID461-0161384-z.

Pitout, H. (2014). Barriers and strategies to increase research involvement of South African occupational therapists. South African Journal of Occupational Therapy, 44 (2), 17 -21

Sulo, T., Kendagor, R., Kosgei, D., Tuitoek, D. \& Chelangat, S. (2012). Factors affecting research productivity in public universities of Kenya: Journal of Emerging Trends in Economics and Management Sciences (JETEMS), 3 (5), 475-484.

Wadesango, N. (2014). Publish or perish: impediment to research output and publication. International Journal Education Science, 6 (1), 57-63. 